\title{
Correlation of Cardiorespiratory Fitness with Fatigue Severity Scale (FSS) on Systemic Lupus Erythematosus (SLE) Patients at RSUP Dr. Hasan Sadikin Bandung
}

\section{Thea Yovita ${ }^{1}$, Sumartini Dewi², Sunaryo Barki Sastradimaja ${ }^{3}$}

${ }^{1}$ Faculty of Medicine, Universitas Padjadjaran, Bandung.

2Division of Rheumatology, Department of Internal Medicine, Faculty of Medicine, Universitas Padjadjaran, dr. Hasan Sadikin General Hospital, Bandung.

${ }^{3}$ Department of Physical and Rehabilitation Medicine, Faculty of Medicine, Universitas Padjadjaran, dr. Hasan Sadikin General Hospital, Bandung

\author{
A R T I C L E I N F O \\ Keywords: \\ Cardiorespiratory Fitness \\ Fatigue Severity Scale \\ SLE \\ Corresponding author: \\ E-mail address: \\ thea.yovita@gmail.com \\ All authors have reviewed and \\ approved the final version of the \\ manuscript.
}

https://doi.org/10.37275/IJR.v11i2.127

\begin{abstract}
A B S T R A C T
Background Systemic Lupus Erythematosus (SLE) is a multifactorial and heterogenous systemic autoimmune disease, involving multisystem organ and marked with the production of autoantibodies. SLE has general constitutional sympton such as fatigue and usually is the main symptom causing limited functional condition on patients. Assessment for cardiorespiratory fitness can be done with various methods, one of them measuring Metabolic Equivalents (METs). The purpose of this study was to examine the correlation between cardiorespiratory fitness and Fatigue Severity Scale (FSS). Methods The sampling method used was the total sampling method. Out-patients diagnosed with SLE were screened via medical records according to inclusion and exclusion criteria. SLE patients filled an Indonesian version of the FSS questionnaire sheet and did the six-minute walk test based on standard protocol on a 30-meter track. The total distance patients had crossed was turned into $\mathrm{VO}_{2}$ max with Nury equation, then turned again into cardiorespiratory fitness with METs unit. A correlation analysis between cardiorespiratory fitness and FSS was done next. Results There were 28 patients participating in this research. Correlation analysis resulted in a negative correlation with no statistical meaning between cardiorespiratory fitness and FSS $(r=-0,27 ; \mathrm{p}>0,05)$. Conclusion There is no correlation between cardiorespiratory fitness and FSS in SLE patients.
\end{abstract}

\section{Introduction}

Systemic Lupus Erythematosus (SLE) is a multifactorial and heterogenous systemic autoimmune disease, involving multisystem organ and marked with the production of autoantibodies. ${ }^{1}$ SLE can affect all organs in a human body. ${ }^{2}$ Fatigue is the most common constitutional sympton 
$(80 \%)$ of SLE, usually the main symptom causing limited functional condition on patients. ${ }^{1,3}$ Grace E. Ahn and Rosalind Ramsey-Goldman in their research in 2012 showed that SLE patients had higher fatigue level than the healthy population. ${ }^{4}$ This condition can downgrade the intensity and the frequency of daily physical activities, worsening patients' disability state. ${ }^{3}$ Patient with unmet World Health Organization (WHO) recommendation for physical activities tends to have higher disease progressivity. ${ }^{5}$

SLE patients have lower aerobic fitness and exercise capacity level than control population; this physical disability corresponds to the high level of fatigue. ${ }^{6}$ Sandor Balsamo and Leopoldo dos Santos-Neto's research in 2011 also pointed that SLE patients had lower cardiorespiratory capacity compared to healthy subjects. ${ }^{7}$ Initiation of physical activities and the decrease in sedentary time are important to be done because they can help reduce fatigue level.5,8,9 Until recently, treatments for SLE have not been optimal, making it important for patients, their surroundings, and medical personnel to understand the SLE patients' cardiorespiratory status and its correlation with fatigue level as the basic of promotive preventive act. 10 Many studies examine cardiorespiratory fitness with Metabolic Equivalents (METs) measurement and the maximum $\mathrm{O}_{2}$ volume $\left(\mathrm{VO}_{2} \max \right)$ using direct method. ${ }^{11}$ This direct measurement requires several conditions such as specialized tools and qualified examiners, making it difficult to be conducted in general setting, thus a field test like the six-minute walk test can be an alternative choice. ${ }^{12}$ The sixminute walk test has been widely use in various studies to assess the quality of patients' life and cardiorespiratory fitness on SLE patients and other disease alike. In the global scale, there has been a comparative study about the result of the six-minute walk test and the quality of life on pre-menopause SLE patients compared to the control population; SLE patients ambulated shorter distance compared to control population and can be associated with worse quality of life. ${ }^{13}$ Research done by Colin Tech et al. in 2002 studying aerobic fitness, muscle strength, and physical disabilities in SLE patients using treadmill-walking test indicated that physical disabilities could be determined from aerobic fitness and related with fatigue. There has been no study published about the correlation between cardiorespiratory fitness and the six-minute walk test with fatigue level on SLE patients in Indonesia and overseas.

Research about the correlation of cardiorespiratory fitness with fatigue level in SLE patients is expected to be able to give clinicians, the public, and especially SLE patients themselves informations on the importance of prevention, detection, and early intervention on cardiorespiratory alteration signs along with the importance of routine measurable physical activities. This research is also hoped to be able to motivate SLE patients in increasing daily activities to counter fatigue, as well as to become one of the base theory for clinicians to suggest physical exercise regimes for SLE patients.

\section{Methods}


This study used cross sectional study design. The data was taken with the Indonesian version of Fatigue Severity Scale (FSS) questionnaire to determine the fatigue level and the sixminute walk test were done to determine the cardiorespiratory fitness on out-patients diagnosed with SLE coming to control at the Rheumatology Polyclinic, Departement of Internal Medicine, dr. Hasan Sadikin General Hospital from September to October 2019 , followed with a correlation test.

Inclusion criteria were those ranging from 18 to 50 years old, having normal Body Mass Index (BMI) $(18,5-$ $\left.24,9 \mathrm{~kg} / \mathrm{m}^{2}\right)^{14}$, newest MEX-SLEDAI score $\leq 5$, and the ability to walk independently both by themselves or with assisting walking aids such as a walking cane. Exclusion criteria were the presence of absolute contraindications from the six-minute walk test such as unstable angina and myocardium infarction a month before, the existence of relative contraindications from the six-minute walk test such resting heart rate more than 120 , systolic blood pressure $>180$ $\mathrm{mmHg}$, and diastolic blood pressure $>100 \mathrm{mmHg}^{15}$, and having musculosceletal, respiratory, cardiopulmonal, or other systemic diseases which are not related to SLE.

The study was done after gaining ethical approval number 872/UN6.KEP/EC/2019 by Ethical Committee of Faculty of Medicine, Universitas Padjadjaran and research permit number LB.02.01/X.2.2.1/13594/2019 by dr. Hasan Sadikin General Hospital Bandung.

Sampling method used was the total sampling method, in which all population meeting the research criteria was used as samples. Minimum sum of samples was calculated using correlative analysis' minimum sum of samples equation with $Z_{\alpha}=5 \%$ and $Z_{\beta}=$ $10 \%$. In this study, $r$ value had not been determined yet because there was no reference found from previous literature study, resulting in conducting a preliminary study on the first ten patients to find the $r$ value. Based on the preliminary study, the value found was $r=-0.70$, thus the minimum sum of samples were 19 patients.

First, screening on out-patients diagnosed with SLE coming to control at the Internal Medicine section of the Rheumatology Polyclinic dr. Hasan Sadikin General Hospital Bandung was done through medical records based on inclusion and exclusion criteria. Clinical manifestation at the time of SLE diagnosis data collecting was obtained from Hasan Sadikin Lupus Registry by the Rheumatology Division of the Department of Internal Medicine dr. Hasan Sadikin General Hospital Bandung. The data were classified based on SLE diagnosis criteria from the American College of Rheumatology (ACR). ${ }^{16}$ SLE patients willing to participate in this research and had filled the infomed consent sheet then filled the Indonesian version of the Fatigue Severity Scale (FSS) questionnaire sheet which had the validity and reliability test done before. ${ }^{17}$ SLE patients then did the sixminutes walk test on the same day according to the standard procedure from ATS Statement: Guidelines for the Six-Minute Walk Test from American Thoracic Society (ATS) on a 30-meter track. ${ }^{15}$ Total distance ambulated by patients was turned into $\mathrm{VO}_{2}$ max with Nury equation ${ }^{18}$, then the calculation resut was turned again into cardiorespiratory fitness with METs unit based on Adult Compendium of 
Physical Activities in 2011.19

Data collected were analyzed with statistical software IBM SPPS Statistics version 25.0. Data analysis of the correlation between cardiorespiratory fitness and FSS was done using Pearson correlation.

\section{Result}

Until the end of the study period, there were 28 cardiorespiratory fitness and FSS data obtained from SLE patients meeting the criteria. Subject demography data for this research were representated in Table 1. All 28 patients $(100 \%)$ of this research were females. The mean of patients' age was 30 years old, with mean height 155,64 centimeters and mean weight 53,07 kilograms. The most common clinical manifestation according to diagnosis criteria from the American College of Rheumatology (ACR) were positive Antinuclear Antibody (ANA) test (28 patients; $100 \%)$, arthritis (24 patients; $85,7 \%)$ and hematological and immunological abnormality each numbering 16 patients $(57,1 \%)$.

Table 1 Demographic data of Systemic Lupus Erythematosus (SLE) patients

\begin{tabular}{lc}
\hline \multicolumn{1}{c}{ Research Variables } & SLE Patients (n=28) \\
\hline $\begin{array}{l}\text { Age (years) } \\
\text { Height (cm) }\end{array}$ & $30,04(8,81)$ \\
Weight (kg) $^{\mathbf{a}}$ & $155,64(7,10)$ \\
Biological Sex $^{\mathbf{b}}$ & $53,07(7,71)$ \\
- Male & $0(0 \%)$ \\
- Female & $28(100 \%)$ \\
Clinical manifestations at the time of SLE diagnosis & \\
- Malar rash & \\
- Discoid rash & $14(50 \%)$ \\
- Photosensitivity & $9(32,1 \%)$ \\
- Oral ulcer & $10(35,7 \%)$ \\
- Arthritis & $10(35,7 \%)$ \\
- Serositis & $24(85,7 \%)$ \\
- Nenal abnormality & $4(14,3 \%)$ \\
- Heurological abnormality & $16(57,1 \%)$ \\
- Immunological abnormality & $5(17,9 \%)$ \\
- Antinuclear Antibody (ANA) & $16(57,1 \%)$ \\
& $9(32,1 \%)$ \\
${ }^{a}$ Mean(SD)/ ${ }^{b}$ Sum(Percentage)/ cMedian (Minimum-Maximum) & $28(100 \%)$ \\
Details: 1 patient might have $>1$ manifestation &
\end{tabular}

Table 2. FSS and cardiorespiratory fitness data from SLE patients 
Fatigue Severity Scale Score

- Statement $1^{\mathrm{a}}$

- $\quad$ Statement $2^{\mathrm{b}}$

$4(1-7)$

- $\quad$ Statement $3^{\mathrm{b}}$

$4,18(1,70)$

$3,86(1,72)$

$4(1-7)$

- Statement $4^{a}$

$3,96(1,77)$

- Statement 6a

$5(1-7)$

$4(1-7)$

- Statement $7^{a}$

$4,11(1,73)$

- Statement $8^{\mathrm{b}}$

$4(1-7)$

Six-minute walk test distance $(\mathrm{m})^{\mathrm{b}}$

$394,88(65,88)$

$\mathrm{VO}_{2} \max (\mathrm{mL} / \mathbf{k g} / \text { minute) })^{\mathbf{b}}$

$13,35(3,74)$

aMedian (Minimum-Maximum)/ ${ }^{b}$ Mean(SD)

Table 3. Correlation coefficient between cardiorespiratory fitness and Fatigue Severity Scale (FSS)

\begin{tabular}{lcc}
\hline \multicolumn{1}{c}{ Research Variables } & SLE Patients (n=28) & r (p) \\
\hline Cardiorespiratory fitness (METs) $^{\mathbf{a}}$ & $3,81(1,07)$ & \\
Fatigue Severity Scale score $^{\mathbf{a}}$ & $4,04(1,50)$ & $-0,27(0,16)$ \\
\hline
\end{tabular}

SLE: Systemic Lupus Erythematosus

METs: Metabolic Equivalents

${ }^{a} \operatorname{Mean}(S D)$

\section{Discussion}

Median age of the study subjects was 30 years old with female being the dominant sex (100\%). This matches with Infodatin: Situasi Lupus di Indonesia (Centers of Data and Information: Lupus Condition in Indonesia) published by Ministry of Health Indonesia in 2017 which stated that those in productive age group (15 to 50 years old) were prone to SLE. ${ }^{20}$ The study done by Frances Rees et al. about the systematical review of SLE prevalence and incidence all around the globe pointed out that the peak incidence age of women is between 30 to 70 years old; meanwhile men is between 50 to 70 years old. The same study stated that women were more prone to SLE than men with ratio between 2:1 and 15:1.21 Other research conducted by Lani Hamijoyo et al. at dr. Hasan Sadikin General Hospital Bandung indicated that female was the dominant sex in the demography data of SLE patients. ${ }^{22}$

The most common clinical manifestation based on the diagnosis criteria from the American College of Rheumatology (ACR) were positive Antinuclear Antibody (ANA) test (28 patients; 100\%), arthritis (24 patients; $85,7 \%)$ and hematological and immunological abnormality each numbering 16 patients $(57,1 \%)$. This result slightly differs from another study done by Lani Hamijoyo et al. at dr. Hasan Sadikin General Hospital Bandung which denoted arthritis (75.5\%), malar rash (68.3\%), and photosensitivity $(60.6 \%)$ with most patients having a positive ANA test $(98.4 \%)$ as the most common clinical manifestation. ${ }^{22}$

FSS mean score of the study subjects was 4,04. A study conducted by Yuan Zhuang et al. in China examined FSS score 
on SLE patients with cutoff score $\geq 4$ to define fatigue in case and control, interpreting the higher the FSS score the more severe the fatigue. ${ }^{23}$ This showed that fatigue was found in study subject. Grace E. Ahn and Rosalind Ramsey-Goldman in their research in the United States of America indicated that SLE patients had higher fatigue level than the healthy population. ${ }^{4}$

$$
\text { Many }
$$

studies express

cardiorespiratory fitness in the form of Metabolic Equivalents (METs). ${ }^{11}$ The MET term based on Adult Compendium of Physical Activities in 2011 were the result of energy cost $\left(\mathrm{VO}_{2} \mathrm{~mL} / \mathrm{kg} /\right.$ menit) divided with 3,5 $\mathrm{mL} / \mathrm{kg} /$ minute. ${ }^{19}$ METs can be assessed from many tests chosen based on patients, conditions, and equipments and trained personnel available. The six-minute walk test is one the field test used to evaluate cardiorespiratory fitness. ${ }^{24}$ Data analysis result showed the mean distance of the study subjects on the six-minute walk test was 394,88 meters. In a study done by Nur Nusdwinuringtyas et al. examining the validity and reliability of the six-minute walk test on the 15-meters track at Universitas Indonesia, mean track distance of healthy patients obtained was 516,72 meters for female and 581,89 meters for male. ${ }^{25}$ Another study at the same university by Fathia Arsyiana showed the mean distance of SLE patients on the six-minute walk test was 364,35 meters. ${ }^{26}$ Study done by Sandor Balsamo et al. in Brazil stated that pre-menopause SLE women ambulated shorter mean distance (598 meter) compared to control population (642 meter). ${ }^{13}$

In this study, the mean $\mathrm{VO}_{2}$ max was $13,35 \mathrm{~mL} / \mathrm{kg} /$ minute. Study at Universitas Negeri Surabaya by Wahyu Setyawan and Juanita Dolores H.N., $\mathrm{VO}_{2}$ max in high school-level students examined with Multistage Fitness Test (MFT) was 33,29 $\mathrm{mL} / \mathrm{kg} /$ minute. ${ }^{27}$ Another study conducted by Revina Andayani et al. at Universitas
Muhammadiyah Surakarta showed mean $\mathrm{VO}_{2}$ max of college students who regularly exercised $(71,55 \mathrm{~mL} / \mathrm{kg} / \mathrm{menit})$ is higher than those who did not $(57,12$ $\mathrm{mL} / \mathrm{kg} / \mathrm{menit}) .{ }^{28}$ A study done by Randall E. Keyser et al. at the United States of America measuring $\mathrm{VO}_{2}$ peak on female SLE patients (case) using treadmill showed lower result $(20,1 \mathrm{~mL} / \mathrm{kg} /$ menit) compared to that of control population $(28,9$ $\mathrm{mL} / \mathrm{kg} /$ minute). ${ }^{29}$

Mean METs of the subjects was 3,81. According to O'Dwyer T et al., SLE patients encounter more limitations in doing physical activity: arthritis, arthralgia and avascular necrosis, serositis, lungs involvement, fatigue, depression, and other comorbidities. ${ }^{9}$ Research done by Sandor Balsamo et al. indicated that SLE patients had lower cardiorespiratory capacity and muscle strength compared to healthy subjects. 7

Based on correlation analysis result, there was a negative correlation with no statistical meaning between cardiorespiratory fitness and FSS ( $r$ value $=$ $-0,27 ; p>0,05)$. In studies existed, fatigue in SLE patients might correspond with physical activity and would eventually reduce the intensity and frequency of daily physical activities. ${ }^{3,4}$ Patients caught up in sedentary lifestyle appear more exhausted, further limiting daily physical activites and prolonging their sedentary time, thus experiencing in worse fatigue. 5 Sedentary lifestyle may worsen SLE symptoms which results in the decrease of functional capacity. ${ }^{3}$ This is supported by a study showing SLE patients with lower cardiorespiratory capacity than healthy subjects. ${ }^{7}$ In a study led by Benjamin Y. Tseng and Patricia Kluding researching patients with chronic stroke, a significant negative correlation between fatigue level and $\mathrm{VO}_{2}$ peak was obtained, although it did not correlate with the six-minute walk test. ${ }^{30}$ Research conducted by Colin Tench et al. pointed out that SLE patients had 
lower aerobic fitness and exercise capacity level than control population. This physical disability is related to the high level of fatigue, aerobic fitness, BMI, and depression. ${ }^{6}$

\section{Limitation}

The limitations of this study included several aspects. This study used FSS questionnaire which has 90\% sensitivity and $84 \%$ specificity to mesure Chronic Fatigue Syndrome (CFS). Further research can be done using fatigue questionnaire with the best sensitivity and specificity according to existing study, e.g. ME/CFS Fatigue Types Questionnare (MFTQ) PostExertional Fatigue Scale which is the best scale with $95 \%$ sensitivity and $86 \% .^{31}$

Fatigue in SLE can be affected by physical activities, quality of sleep, obesity, emotional condition, deficiency/insufficiency of vitamin D, comorbidity, related to the SLE itself, or other medications used for SLE therapy. The study shows no significant difference between fatigue in patients with corticosteroid treatment, nonsteroidal antiinflammatory drugs (NSAIDs), and psychotropic medication and those without. ${ }^{4}$ Another study shows that pain, depression, and stress play a role in fatigue level in SLE patients, meanwhile disease activity, physical healtiness, and sleep have no correlation. ${ }^{32}$ In a further study, the correlation of those factors with fatigue level can be assessed, resulting in a more accurate conclusion.

This study did not measure factors corresponding with fatigue level and cardiorespiratory fitness (six-minute walk test and $\mathrm{VO}_{2} \max$ ). The six-minute walk test is influenced by a couple of deteminants: age, sex, height, weight, Forced Expiratory Volume (FEV), and ethnics. ${ }^{34}$ Further research can involve more thorough assessment via collecting and measuring on FEV and ethnics. Other factors affecting $\mathrm{VO}_{2}$ max such as genetics, age, sex, physical activities, body fat, smoking status, and medical conditions can also be considered for further research. ${ }^{35}$ Physical activity has several measurement methods, including self-reporting questionnaires as the most commonly used, so that further study could consider physical activity assessment using the Indonesian version of questionnaires which have already had validity and reliability test. 36

\section{Conclusion}

There is no correlation between cardiorespiratory fitness and FSS in SLE patients. Further study using the most accurate existing questionnaire of fatigue level and assessing factors which could affect the variables measured is recommended in order to achieve more accurate conclusion.

\section{Acknowledgement}

Researcher would like to thank the Rheumatology Polyclinic, Departement of Internal Medicine, dr. Hasan Sadikin General Hospital as well as dr. Nadia Gita Ghassani and dr. Laniyati Hamijoyo SpPDKR, M.Kes. from SLE Study Group dr. Hasan Sadikin General Hospital Bandung for their help in completing the study data.

\section{References}

1. J. Wallace D, Hahn BH. Dubois' Lupus Erythematosus and Related Syndromes. 8th ed. USA: Elsevier Inc.; 2019. p. 393.

2. Centers for Diseases Control and Prevention. Systemic Lupus Erythematosus (SLE). [cited 2019 Mar 2]. Available from: https://www.cdc.gov/.

3. Sallum AME, Borba E, Sá- AL De, Paulo S, Division R, Paulo S, et al. Reduced Aerobic Capacity and Quality of Life in Physically Inactive Patients with Systemic Lupus Erythematosus with Mild/Inactive 
Disease. Arthritis Care \& Research. 2016;68(12):1780-6.

4. Ahn, Grace E., and Rosalind RamseyGoldman. Fatigue in Systemic Lupus Erythematosus. Int J Clin Rheumtol. 2012;7(2):217-27.

5. Margiotta DPE, Basta F, Dolcini G, Batani V, Lo Vullo M, Vernuccio A, et al. Physical Activity and Sedentary Behavior in Patients with Systemic Lupus Erythematosus. PloS one. 2018 Mar 5;13(3):e0193728.

6. Tench C, Bentley D, Vleck V, Mccurdie I, White P, Cruz DD, et al. Aerobic Fitness, Fatigue, and Physical Disability in Systemic Lupus Erythematosus. 2002;29(3).

7. Balsamo S, Santos-Neto L dos. Fatigue in Systemic Lupus Erythematosus: An Association with Reduced Physical Fitness. Autoimmun Rev. 2011;10(9):514-8.

8. Olesińska M, Saletra A. Quality of Life in Systemic Lupus Erythematosus and Its Measurement. Reumatologia. 2018;56(1):45.

9. O'Dwyer T, Durcan L, Wilson F. Exercise and Physical Activity in Systemic Lupus Erythematosus: A Systematic Review with MetaAnalyses. Semin Arthritis Rheum. 2017 Oct $1 ; 47(2): 204-15$.

10. He J, Li Z. An Era of Biological Treatment in Systemic Lupus Erythematosus. Clin Rheumatol. 2018;37(1):1-3.

11. Ross R, Blair SN, Arena R, Church TS, Després JP, Franklin BA, et al. Importance of Assessing Cardiorespiratory Fitness in Clinical Practice: A Case for Fitness as a
Clinical Vital Sign: A Scientific Statement from the American Heart Association. Vol. 134, Circulation. 2016. p. 653-699.

12. Jalili M, Nazem F, Sazvar A, Ranjbar K. Prediction of Maximal Oxygen Uptake by Six-Minute Walk Test and Body Mass Index in Healthy Boys. J Pediatr. 2018;200:155-9.

13. Balsamo S, Nascimento C, Tibana RA, Santana FS De. The Quality of Life of Patients with Lupus Erythematosus Influences Cardiovascular Capacity in 6-Minute Walk Test. Rev Bras Reumatol. 2013;53(1):75-80,86-87.

14. World Health Organization. The AsiaPacific Perspective: Redefining Obesity and Its Treatment. Geneva, Switzerland: World Health Organization. 2000. p. 56

15. American Thoracic Society. American Thoracic Society ATS Statement: Guidelines for the Six-Minute Walk Test. 2002;166:111-7.

16. Hochberg MC. Updating the American College of Rheumatology Revised Criteria for the Classification of Systemic Lupus Erythematosus. Arthritis Rheum 1997;40(9):1725.

17. Rifa'i A, Kalim H, Handono K, Wahono CS. Validity and Reliability Fatigue Severity Scale in Patients with Systemic Lupus Erythematosus (SLE) in Indonesia. Indonesian Journal of Rheumatology.;8(1).

18. Nusdwinuringtyas N, Laksmi W, Bachtiar A. Healthy Adults Maximum Oxygen Uptake Prediction from A Six Minute Walking Test. 2011;20(3):195-200.

19. Ainsworth BE, Haskell WL, 
Herrmann SD, Meckes N, Bassett Jr DR, Tudor-Locke C, et al. Compendium of Physical Activities 2011: A Second Update of Codes and MET Values. Medicine and Science in Sports and Exercise, 2011;43(8):1575-1581.

20. Ministry of Health Indonesia [Kementrian Kesehataan RI]. Centers of Data and Information: Lupus Condition in Indonesia [Infodatin: Situasi Lupus di Indonesia]. 2017. p. 3-5.

21. Rees F, Doherty M, Grainge MJ, Lanyon P, Zhang W. The Worldwide Incidence and Prevalence of Systemic Lupus Erythematosus: A Systematic Review of Epidemiological Studies. Rheumatol (United Kingdom). 2017;56(11):1945-61.

22. Hamijoyo L, Candrianita S, Rahmadi AR, Dewi S, Darmawan G, Suryajaya BS, et al. The clinical Characteristics of Systemic Lupus Erythematosus Patients in Indonesia: A Cohort Registry from an Indonesia-Based Tertiary Referral Hospital. Lupus. 2019;1--6.

23. Du X, Zhao Q, Zhuang $Y$, Chen $\mathrm{H}$, Shen B. Fatigue of Systemic Lupus Erythematosus in China: Contributors and Effects on The Quality of Life. Patient preference and adherence. 2018;12:1729.

24. American College of Sports Medicine. ACSM's Exercise Testing and Prescription. 10 $10^{\text {th }}$ ed. Philadelphia: Wolters Kluwer Health; 2018.

25. Nusdwinuringtyas N, Alwi I, Yunus F. Validity and Reliability of the 6Minutes Walk Test on the 15-Meters Track [Kesahihan dan Keandalan Uji
Jalan Enam Menit pada Lintasan 15 Meter]. Media of Research and Development of Health [Media Penelitian dan Pengembangan Kesehatan]. 2018 Oct 17;28(2):1316.

26. Arsyiana, Fathia. Effect of Walking Exercise To Borg Scale Value and Six Minutes Walking Test Distance in Systemic Lupus Erythematosus Patients [Pengaruh Latihan Berjalan Terhadap Nilai Skala Borg dan Jarak Tempuh Uji Jalan Enam Menit Pada Pasien Lupus Eritematosus Sistemik] [specialist thesis]. [Jakarta]: Universitas Indonesia School of Medicine; 2012.

27. Setyawan W, HN Juanita D. Comparison of Cardiorespiratory Fitness between Smoker Students and Non-smoke: A Study on Students Attending Shorinji Kempo Extracurricular at MAN Purwoasri and SMKN 1 Ngasem, Kediri [Perbandingan Daya Tahan Kardiorespirasi Antara Siswa Perokok dan Siswa Tidak Perokok: Studi Pada Siswa Ektrakurikuler Beladiri Shorinji Kempo MAN Purwoasri dan SMKN 1 Ngasem Kabupaten Kediri] [minor thesis]. 2017;05:798-803.

28. Andayani S, Suryaningsih R, Basuki SW. Comparison of Mean $\mathrm{VO}_{2} \max$ between Students who Regularly Exercised and who did not at Universitas Tunas Pembangunan Surakarta [Perbedaan Rerata Nilai VO2 Maks antara Mahasiswa yang Teratur Berolahraga dan Mahasiswa yang Tidak Teratur Berolahraga di Universitas Tunas Pembangunan 
Surakarta] [minor thesis]. 2012;1-16.

29. Keyser RE, Rus V, Mikdashi JA, Handwerger BS. Exploratory Study on Oxygen Consumption On-Kinetics During Treadmill Walking in Women with Systemic Lupus Erythematosus. Archives of Physical Medicine and Rehabilitation. $2010 \quad$ Sep 1;91(9):1402-9.Ross RM, Murthy JN, Wollak ID, Jackson AS. The Six Minute Walk Test Accurately Estimates Mean Peak Oxygen Uptake. BMC Pulm Med. 2010;10.

30. Tseng BY, Kluding P. The Relationship between Fatigue, Aerobic Fitness, and Motor Control, in People with Chronic Stroke. A Pilot Study. Journal of geriatric physical therapy (2001). 2009;32(3):97.

31. Jason LA, Evans M, Brown M, Porter N, Brown A, Hunnell J, Anderson V, Lerch A. Fatigue scales and chronic fatigue syndrome: Issues of sensitivity and specificity. Disability studies quarterly: DSQ. 2011;31(1).

32. Azizoddin DR, Gandhi N, Weinberg S, Sengupta M, Nicassio PM, Jolly M. Fatigue in systemic lupus: the role of disease activity and its correlates. Lupus. 2019 Feb;28(2):163-73.

33. Asih, Rizky Ayu Fandika. Factors associated with fatigue in patients Systemic Lupus Erythematosus (SLE) at Indonesian Lupus Panggon Kupu Foundation in Semarang City [Faktor-faktor yang Berhubungan dengan Kelelahan pada Pasien Systemic Lupus Erythematosus (SLE) di Yayasan Lupus Indonesia Panggon Kupu Semarang] [minor thesis]. [Semarang]: Semarang State University Sport Science Faculty; 2015.

34. Rasekaba T, Lee AL, Naughton MT, Williams TJ, Holland AE. The SixMinute Walk Test : A Useful Metric for The Cardiopulmonary Patient. 2009;39:495-501.

35. Mundwiler J, Schüpbach U, Dieterle T, Leuppi JD, Schmidt-Trucksäss A, Wolfer DP, et al. Association of Occupational and Leisure-Time Physical Activity with Aerobic Capacity in A Working Population. PLoS one. 2017;1-15.

36. Sylvia LG, Bernstein EE, Hubbard JL, Keating L, Anderson EJ. Practical Guide to Measuring Physical Activity. Journal of the Academy of Nutrition and Dietetics. $2014 \quad$ Feb 1;114(2):199-208. 